\title{
Alterity Issues and the Roots of Western Views on Islam and Oriental Society
}

\author{
Edvin Cami \\ University "Aleksandër Moisiu", Durrës \\ E-mail: cami@daad-alumni.de
}

\section{Doi:10.5901/ajis.2013.v2n1p473}

\begin{abstract}
The article is focused in the so called "phenomenon of encounter with the other" in the context of social, literary and cultural encounters between the West and the Islamic society and religion. In the flow of history, since the Middle Ages, theological polemics and military clashes have shaped a canonic view of Christendom toward Islam, and later of the West and post-Christian societies to the Near Eastern and Middle Eastern societies. The ways such a view, based on a "doctrine about doctrine" or "belief on the enemy's beliefs", emerged and was established, and the assertion that it still exerts its influence in the modern day's world with implications in social, cultural and political relations are part of the focus of this article.
\end{abstract}

Keywords: encounter with the other, Islam, Christendom, West, Orient, middle Ages, Enlightenment,

\section{Introduction: Encounter with the (Distorted) Other}

The phenomenon of encounter with the other (rencontre avec l'autre) is especially important in the conception of an imagology of the alien. It constitutes an important subject in the social sciences, while especially considered by Yves Chevrel as the central phenomenon of comparative approaches in the literary science. To explain the essence and the central focus of this phenomenon, and beside this to "legitimate" it within the context of comparative research in literature, he (p. 8) states:

\begin{abstract}
Que se passe-t-il quant une conscience humaine, intégrée dans une culture (dans sa culture), est confrontée à une œuvre expression et partie prenante d'une autre culture? Autrement dit, la rencontre, provoquée ou non, avec l'étranger, avec celui ou celle qui ne parle pas la même langue, qui n'a pas la même culture, qui est, tant que je ne fais pas l'effort de le comprendre, un «barbarus » (dont je n'entends que «ba, ba», des phonèmes qui ne font pas sens) - mais la réciproque est non moins vraie, sauf si j'ai la chance de m'exprimer dans une langue dite universelle -, la rencontre avec l'autre est au cœur de la démarche comparatiste, et on peut dire qu'elle suffit à la légitimer. ${ }^{1}$
\end{abstract}

Due to the implied conceptual, cultural and linguistic distances and discrepancies, this encounter with the other occurs often on a background of clichés, stereotypes, and distorted images and this is also the case of the perception of Islam and the Orient by the Western society, based on a long tradition of religious, theological and social conflict and polemics between Islam and Christendom, starting since the Middle Ages and reaching until the modern days. As N. Daniel (p. 12) states,

\footnotetext{
People seem to take it for granted that an alien society is dangerous, if not hostile, and the spasmodic outbreak of warfare between Islam and Christendom throughout history has been one manifestation of this. Apparently, under the pressure of their sense of danger, whether real or imagined, a deformed image of their enemy's beliefs takes shape in men's minds. [...] A "real truth" is identified: this is something that contrasts with what the enemy say they believe; they must not be
}

\footnotetext{
1 What happens as a human conscience, integrated in a culture (in its own culture) is confronted with a work that is an expression and part of another culture? In other words, the meeting, provoked or not, with the stranger, that does not possess the same culture, that is, as long as l've not tried to understand him, a "barbarus" (what I hear is only "ba, ba", phonemes that do not make any sense) - but the reciprocal is equally true, unless I have the chance to express myself in a language called universal -, the encounter with the other is at the heart of the comparative approach, and arguably sufficient to legitimize it. [All translations belong to the author] 
allowed to speak for themselves. This doctrine about doctrine is widely repeated, and confirmed by repetition in slightly varying forms."

But this "doctrine about doctrine" and the respective distorted images, in spite of being confirmed by repetition among the mass of ordinary people, are not a product of the less educated strata of a society or community. On the contrary, as Daniel (ibid.) affirms, "The experts, perhaps because being close to the facts is a constant stimulus to their zeal, contribute most to the process, and they are themselves of course wholly convinced by it."

\section{A Canon of Beliefs on the Enemy's Belief}

The contribution of the above mentioned experts in the framework of Christendom's political opposition to the Islamic society led already in very early stages in the case of the Western view of Islam to a kind of communal mode of thought, which was established in a great internal coherence, representing a doctrinal unity on the enemy's doctrine. This doctrinal unity, as a powerful polemic framework, took shape especially after Christians seized power in formerly Muslim areas such as Spain, establishing thus a canon of beliefs of (Western) Christians on the Muslims' belief; a canon that has survived with slight differences until nowadays in the Western society. (Daniel, p. 302) Characterizing the quality of this canon, Daniel (ibid.) states that "it was based in the crucial period on a good deal of sound knowledge, but it also accepted a great deal that is now seen, and was seen by many than too, to be nonsense. Nonsense was accepted, and sound sense was distorted, because whatever seemed useful to faith was thought likely to be true, a failure of logic, and indeed of faith as well, which is not peculiar to this subject or these people."

\section{The Essence of the Canon}

"Corano maledetto! Maledette le lettere che ti compongono! Maledetta la penna che l'ha scritto! Maledetto l'autore che l'ha vomitato al mondo! Maledetti voi tutti che l'osservate!" 2 (Pietro, 3, p. 87; Smith, p. 15) These are the words pronounced by the friar Farncesco da Spoleto in his missionary call to the Muslims of Dumyat in Egypt in 1228, constituting an interesting illustration of the polemic atmosphere establishing in some early period the Christian beliefs on the Islamic enemy. In a similar spirit, Father Tomas of Tollentino (d. 1322) would preach to Muslims in Asia: "Maometto è figlio della perdizione. Ė all'inferno con suo padre, il diavolo, e non solo lui, ma tutti coloro che obbediscono alla sua legge pestilenziale, irrazionale ed iniqua, assolutamente contro Dio e la salvezza delle anime." (Cronaca, p. 600; Smith, p. 15) ${ }^{3}$

Father Andrea da Spoleto would beg the Muslims of Fez in Marocco in 1532 in the following way: "Vi supplico di farvi tutti cristiani, perché dovete sapere che non potete salvarvi se non credete nella Santissima Trinità e non ricevete l'acqua battesimale e non riconoscete che tutti voi che siete qui siete perduti e che l'uomo più maledetto che c'è all'inferno è Maometto." (Koehler, 1928, p. 12; Smith, p. 15-16) ${ }^{4}$ While the Spanish father Juan de Prado, preaching in Marrakech of Morocco in the year 1631, would spit on the ground every time after mentioning the name of Muhammad. (Koheler, 1934, p. 79; Smith, p. 16)

Coming to the "concrete" critics, beyond the simple offensive expressions, Riccoldo of Monte Croce (d. 1320) would stress the "irrationality" of Muhammad by considering him a "homo idyota". In a similar way, Ludolph of Saxony (d. 1378) regarded him as "rough and stupid". (Daniel, p. 107) But other polemists, rather than agreeing with Muhammad's being "stupid" and "irrational", would see in him a "magus perfectissimus"; and Mark of Toledo (d. 1216) spoke of him as skilled in letters and mathematics, a magus having led simple people astray. (Daniel, p. 108)

To sum up the old (canonic) Christian view on Islam, Jean Hermant (1650-1725), in his "History of the Heresies", under the voice "Muhommettism", would present the following description:

"Setta composta da tutte le Religioni; riconosce per suo Autore l'infame Maometto che è stato il più grand'Impostore, ed il

\footnotetext{
${ }^{2}$ Cursed Koran! Cursed be the letters composing you! Cursed be the pen that wrote it! Cursed be the author that has vomited it into the world! Cursed be all of you observing it!

${ }^{3}$ Mahomet is the son of perdition. He is in hell with his father, the devil, and not only he, but all those obeying his pestilential, irrational and unfair law, absolutely against God and the salvation of souls.

4 I supplicate you to become all Christians, because you must know that you can't get saved unless you believe in the most Holy Trinity and receive the baptismal water, and unless you recognize that all of you here are perished and that the most cursed man that is in hell is Mahomet. 
più funesto che sia mai stato al Mondo [...] Questo Impostore essendo troppo ignorante per fondare nel Mondo una nuova Religione, si servì di un Monaco Nestoriano detto Sergio, e di altri Giudei per questo disegno, e tutti insieme composero l'Alcorano [...] Procurarono di accomodarlo alla sensualità della natura corrotta, acciocché fosse più facilmente abbracciato dagli uomini. Li scellerati, i ladri, gli empi, e gl'impudichi ritrovandovi il lor conto si dichiararono tutti del partito di Maometto." (Hermant, p. 268; Smith, p. 17)5

This canon of theological and religious essence was propagated and consolidated also through artistic means. Dante Alighieri, in his Divina Comedia (Canto 28) describes Muhammad as "seminator di scandalo e scisma", suffering in the infernal circle of heretics, being torn apart over and over again by the terrible sword of a demon, walking in eternity through a "dolente strada" (ibid.). Giovanni da Modena would paint the description of this suffering scene in a fresco around the year 1400 on the wall of Bolognini Chapel in San Petronio, where it is exhibited until nowadays.

\section{Survival of the Canon}

As Daniel states, "except for some shifts of emphasis and for the increasing neglect of certain arguments", the above summarized views, formed in the two centuries or so after 1100 and firmly established in Europe by the middle of the fourteenth century, outline - with some variety within the wider unity - even nowadays "the Western 'canon' of what constitutes Islam" (Daniel, p. 306).

But focusing in the abovementioned "shift of emphasis", it is to be remarked that the Enlightenment has led to a special ambiguity in the Western (canonic) view about Islam. Muhammad remains still the false prophet constructing a false religion deliberately and imposing it on the world, but now this may be considered also a positive act, a "good thing to do", making him an admirable world conqueror like Alexander or Caesar (Daniel, p. 310) This view, stimulated by the anticlericalism of the day, supported the Christian medieval canon of beliefs about Islam with a new aim, which can be defined rather than a criticism to Islam on a Christian view, a criticism against religion in general on a secular view. Focusing especially on Voltaire's tragedy Le fanatisme ou Mahomet le prophète, Norman Daniel states that the author's attitude at this time (1742) was different from the medieval Christian one only in two respects: "In his tragedy, Fanatisme, ou Mahomet le prophète, he frankly preferred to invent his own legends, rather than use those already circulating, which were apparently not scurrilous enough for his purpose; and his arguments against Islam are not only, like the medieval ones, such as might be used against all revealed religion: they are intended so to be used." (ibid.)

This intentional use of arguments suitable for the attack against religion in general and not simply against Islam was part of the anticlericalism of the day, typical for the Enlightenment. In spite of all declarative efforts for religious tolerance, there was the tendency of displaying the Prophet Muhammad as an impostor no more to support - as in the Middle Age - the idea of any supposed superiority of Christianity against Islam, but to illustrate through Islam the fraud and cheatings of all revealed religions. Although it is argued that the doctrine of the three imposters - Moses, Jesus and Muhammad - is to be attributed to the Emperor Frederick II of Hohenstaufen (d. 1250), writings of such content are to be evidenced only since the beginning of the early Enlightenment. (Mommsen, p. 14-15) In this content, it is to be remarked that the men of the Enlightenment were able even to appraise Muhammad as a kind of more effective or charming imposter compared to Jesus and/or Moses.

\section{Conclusive Notes}

As stated by N. Daniel, a canon of "doctrine about doctrine", a canonic unity of beliefs on the Islamic beliefs and Oriental society has been established since the Middle Ages as a common way of thought and in a great internal coherence in the Christian society of the time, representing a doctrinal unity on what earlier was - and in some circles even nowadays is considered as the "enemy's doctrine". With the well-known developments during the Enlightenment period, the view to this canon changed and positive assertions on the "former enemy" and his beliefs could be also heard, but the content of the canon in its essence didn't change. This canon has survived with some variety within the large unity until the modern

\footnotetext{
${ }^{5} \mathrm{~A}$ sect composed of all religions; recognizes as its author the infamous Mahomet that was the greatest Impostor, and the evilest that has ever been in the world [...] This Imposter, being too ignorant to establish in the World a new Religion, was served by a Nestorian Monk called Sergius and other Jews for this design, and all together they composed the Alkoran [...] They tried to accommodate it to the sensuality of the corrupt nature, so that it could be more easily embraced by men. The wicked, the thieves, and the shameless among people, finding it convenient for them, declared all themselves on the side of Mahomet. 
day, defining the way the West regards the "alien society" of the East, i.e. the Other in its alterity. Further studies would be useful to examine its influence on the social and political thought of the Western society especially in the context of its relations and communication with the Near and Middle East societies today.

\section{References}

Chevrel, Y. (1997), La littérature comparée, Paris: Presses Universitaires de France - PUF.

Daniel, N. (1997) Islam and the West - The Making of an Image, Oxford: Oneworld.

Ranise, P. (1898), Histoire universelle des missions franciscaines d'après le T.R.P. Marcellin de Civezza, Paris: Tolra.

Smith, A. (2003), Conoscere il Corano. II Corano, la Bibbia e la scienza a confronto. Roma: Alethes

Cronaca dei XXIV Generali, in Analecta franciscana, III (1897), Quaracchi

Koehler, H. (1828), Le Bienheureux André de Spolète, Rabat.

Koehler, H. (1934), L'Eglise chrétienne du Maroc et la Mission Franciscaine 1221-1790, Paris: Société D'Éditions Franciscaines.

Hermant, J. (1735), Maomettismo, in Storia delle eresie, Venezia: Pitteri.

Dante, La Divina Commedia. Canto XXVIII, online available: www.mediasoft.it/dante. 